\title{
MODELO DE REDES NEURAIS ARTIFICIAIS EM SUPORTE TECNOLÓGICO À DETECÇÃO DE CARTEIS EM LICITAÇÕES PÚBLICAS
}

\author{
Gerson do Nascimento Silva, Francisco Lopes de Caldas Filho, Vinicius Eloy dos Reis, \\ Bruno Justino Praciano, João Paulo Lustosa e Rafael Timóteo de Sousa Júnior \\ Universidade de Brasília - Departamento de Engenharia Elétrica, Brasília - DF, Brasil - Zipcode 70910-900
}

\begin{abstract}
RESUMO
O Conselho Administrativo de Defesa Econômica - Cade, autarquia federal brasileira vinculada ao Ministério da Justiça e Segurança Pública, é reconhecido como uma agência pública modelo no Brasil e é destaque entre as autoridades antitruste mundo afora. Naturalmente, a excelência técnica e a respeitabilidade perante a sociedade brasileira têm credenciado o Cade a se posicionar fortemente nas grandes discussões nacionais e internacionais acerca da temática antitruste. Nesse contexto, surge a necessidade do uso de tecnologias de inteligência artificial (IA) e seus acessórios de modo a promover tratamento adequado para os dados; como também, a extração de conhecimento (insigths) para tomadas de decisões assertivas. Nesse sentido, a próxima fronteira a explorar é a atuação cada vez mais proativa de modelos paramétricos não-lineares - Redes Neurais Artificiais (RNAs). O presente artigo descreve como a adoção de RNAs possibilitou detecção de indícios de carteis em licitações públicas e, como resultado, gerou subsídio tecnológico que pode ser agregado à Política Antitruste Brasileira, otimizando processos de detecção de Carteis e auxiliando em Programas de Leniência.
\end{abstract}

\section{PALAVRAS-CHAVE}

Investigação e Perícia Contábil, Fraudes, Detecção de Carteis, Aprendizado de Máquina, Redes Neurais

\section{INTRODUÇÃ̃O}

De acordo com a publicação Market Bussiness News, 2017, a Organização para Cooperação e Desenvolvimento Econômico (OECD) enxerga a detecção de conluio nas propostas nas licitações públicas como parte significativa do trabalho das autoridades contratantes; onde se deve discutir as várias formas de conluio em licitações, explicitando as variações temporais e estruturais dos relacionamentos ocultos existentes entre os licitantes, envolvendo subcontratações e permutações dessas licitantes e suas subsidiárias de modo a ofuscar a prática e dificultar sua detecção e investigação. Embora as autoridades promotoras de licitações em geral empreguem ferramentas de detecção reativas para detectar e investigar carteis, uma combinação de medidas tanto reativas quanto proativas de detecção é considerada mais efetiva. Dentre as medidas desta última classe, o uso de algoritmos para detectar licitações colusivas e, mais geralmente, possíveis condutas de cartel, traz possibilidades sem precedentes de colocar a tecnologia a serviço da fiscalização antitruste.

Akhgar et al. (2016) discutem o potencial de aplicar algoritmos de aprendizado de máquina para identificar relacionamentos ocultos como um possível indicador de conluio em licitações públicas.

Já em OECD (2017), há a notícia de que várias agências públicas de controle da concorrência já relataram o uso de varreduras para detectar casos de manipulação de lances, graças à disponibilidade de dados extensos e confiáveis sobre licitações públicas, além da existência de algoritmos capazes de detectar anomalias e padrões suspeitos em grandes conjuntos de dados.

No Brasil, uma das agências públicas responsáveis pelo controle da concorrência é o Conselho Administrativo de Defesa Econômica (Cade), autarquia federal vinculada ao Ministério da Justiça e Segurança Pública (MJSP). O Cade é reconhecido como uma agência pública modelo no Brasil e é destaque entre as autoridades antitruste mundo afora, tendo em especial, no mês de fevereiro do ano de 
2019, guiado o Brasil a ser aceito como membro permanente do Comitê de Concorrência da OCDE, fortalecendo o Sistema Brasileiro de Defesa da Concorrência (SBDC), a partir da troca de experiências com outras jurisdições e da adoção das melhores práticas internacionais.

Nos últimos anos teve-se, por parte da Autarquia, participação protagonista na discussão de temas como setor financeiro, combustíveis, aviação civil, loterias, transporte marítimo, serviços de saúde, dentre vários outros. Sem esquecer, é claro, do transporte individual de passageiros - aplicativos de transporte. Desta forma, sua atuação, em seus diferentes eixos, vem contribuindo para garantir um ambiente concorrencial cada vez mais saudável no país e os frutos colhidos se devem aos incansáveis esforços para adoção de tecnologias de ponta.

O presente artigo apresenta uma iniciativa desenvolvida como uma das atividades do Cade, com auxílio de inteligência artificial, no sentido de obter uma ferramenta de caráter proativo no controle de conluio vinculado a licitações, em particular usando modelos paramétricos não-lineares - redes neurais artificiais (RNA).

As RNA(s) têm a capacidade de generalizar e aprender, adquirindo conhecimento de seu ambiente, adaptando-se os parâmetros internos e externos. A rede aprende com exemplos e se adapta a situações com base nas suas conclusões, generaliza, sobretudo, o conhecimento para produzir respostas adequadas às situações desconhecidas. As redes neurais artificiais, portanto, resolvem problemas complexos.

Assim, conjuntamente com o aparato legislador no tocante a carteis em licitações públicas, que reúne medidas legais, infralegais e organizacionais, o presente artigo contribui para criar um modelo de RNA que subsidie, por meio de tecnologia, a já existente política de combate a cartéis em licitações públicas.

A RNA que é apresentada e discutida no presente artigo teve seu funcionamento e resultados validados em estudo de caso no próprio Cade em que o protótipo desenvolvido da RNA foi submetido a testes com dados de licitações reais, estudo de caso este que também é relatado no texto.

\subsection{O Problema e sua Demarcação}

De que modo o uso de redes neurais artificiais com vistas a elucidar ilícitos contra a ordem econômica, especificamente, carteis em licitações públicas pode auxiliar a tomada de decisão no Conselho Administrativo de Defesa Econômica (Cade).

\section{REFERENCIAL TEÓRICO}

\subsection{Política Antitruste no Brasil}

$\mathrm{O}$ aparato legislador referente à política antitruste brasileira originou-se por meio do Decreto-lei $\mathrm{n}^{\circ} 869$, de 18 de novembro de 1938, com a finalidade de reprimir o abuso do poder econômico e proteger o interesse do consumidor. Desde então foram criados e aperfeiçoados inúmeros instrumentos, normas e procedimentos.

A mais recente legislação que modificou o ambiente da política antitruste brasileira trata- se da lei $n^{\circ}$ 12.529, de 30 de novembro de 2011. Essa norma ampliou as competências do Cade, reestruturando o Sistema Brasileiro de Defesa da Concorrência (SBDC), dispondo, sobretudo, sobre a prevenção e repressão às infrações contra a ordem econômica.

Aspecto importante da norma foi elucidar de que forma/abordagem atua o Cade no tocante ao combate a práticas anticompetitivas. Resume-se, portanto, em três principais abordagens:

a) Preventiva: Por meio do controle de estruturas de mercado. Aprecia-se Atos de Concentração de empresas (fusões, aquisições e incorporações);

b) Repressiva: Por meio do controle de condutas ou práticas anticoncorrenciais. Verificação da existência de infrações à ordem econômica, tais quais: venda casadas, acordos de exclusividade e principalmente a formação de cartel;

c) Educacional: Fomento à cultura concorrencial por meio de parcerias com instituições. 


\subsection{Carteis}

Conforme elucida (Carvalho, 2013) O cartel representa um acordo entre agentes econômicos que atuam no mesmo mercado relevante, visando a construir uma limitação artificial e ilegítima da concorrência.

Apesar de não transcrever diretamente o termo: cartel em sua norma, a Lei $n^{\circ} 12.529 / 2011$, confere em seu parágrafo 3 , inciso I e II o conceito de cartel como conduta caracterizadora de infração à ordem econômica:

$\S 3^{\circ}$ As seguintes condutas, além de outras, na medida em que configurem hipótese prevista no caput deste artigo e seus incisos, caracterizam infração da ordem econômica:

I - Acordar, combinar, manipular ou ajustar com concorrente, sob qualquer forma:

a) os preços de bens ou serviços ofertados individualmente;

b) a produção ou a comercialização de uma quantidade restrita ou limitada de bens ou a prestação de um número, volume ou frequência restrita ou limitada de serviços;

c) a divisão de partes ou segmentos de um mercado atual ou potencial de bens ou serviços, mediante, dentre outros, a distribuição de clientes, fornecedores, regiões ou períodos;

d) preços, condições, vantagens ou abstenção em licitação pública;

II - Promover, obter ou influenciar a adoção de conduta comercial uniforme ou concertada entre concorrentes; grifo nosso. (BRASIL, 2011).

\subsection{Carteis em Licitações Públicas}

Segundo aponta (Nunes, 2016, p. 199) os intuitos dos carteis formados em licitações públicas não diferem dos carteis em geral. A autora considera que a fixação de preços é apenas um desses intuitos.

Conforme referencia, em sua página 9, o Guia Prático para pregoeiros e membros de comissões de licitação, documento editado pelo Ministério da Justiça, há sete ações cartesianas no contexto da licitação pública: Fixação de preços, direcionamento privado da licitação, divisão de mercado, supressão de propostas, apresentação de propostas "proforma”, rodízio e subcontratação.

Atualmente, o principal mecanismo para detecção de indícios de carteis em licitações públicas trata-se do "Programa de Leniência". O programa consiste em firmar acordo de "delação premiada" com participante do cartel. O membro desse cartel denuncia a pratica e todos os respectivos coautores em troca de imunidade administrativa e criminal.

Acredita-se, nessa linha, que a utilização de modelo que detecte de forma automática indícios de carteis possa corroborar com os programas de leniência hoje vigentes no aparato legislador brasileiro.

\subsection{Redes Complexas}

O estudo das redes complexas urgiu como uma área multidisciplinar da Ciência, sendo vista como intercessão entre a mecânica estatística e a teoria dos grafos, que visa estudar e compreender este abrangente fenômeno: como as "coisas" se conectam e quais são as implicações disto. Em sua definição mais geral, uma rede é uma abstração que permite codificar algum tipo de relacionamento entre pares de objetos. Por exemplo, em redes de cartéis objetos são geralmente indivíduos e relacionamentos representam algum tipo de relação social, como amizade ou trabalho em conjunto.

Partindo-se da natureza das Redes Complexas, vê-se que o estudo de redes dinâmicas está em sua infância e até mesmo o significado de suas propriedades precisam ser repensados (Antiqueira et al., 2005). Conforme Figura 1, vê-se exemplo de redes complexas. Essas, conforme entendimento de Strogatz (2001) são muito comuns e podem ser facilmente discernidas em inúmeros cenários, a saber: redes de cartéis, lavagem de dinheiro e diversas outras faces de ilícitos contra a ordem econômica. 


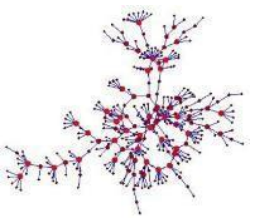

A

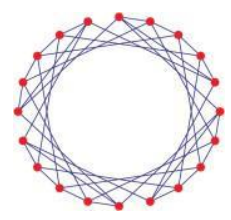

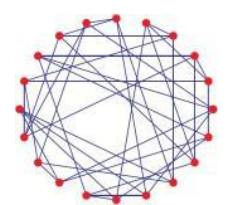

C

Figura 1. Exemplos de redes complexas aplicáveis ao estudo de carteis e/ou lavagem de dinheiro

(Fonte: Adaptado de Strogatz, 2001)

\subsection{Funcionamento do Neurônio Artificial}

Segundo Tafner et al. (1995), uma equipe formada por um neurofisiologista do Massachusetts Institute of Technology (MIT) e um matemático da Universidade de Illinois, Warren S. McCulloch - do MIT e Walter Pitts - de Illinois, definiram o neurônio artificial como uma estrutura que substituí os dendritos por entradas [ xi ], e as ligações ao corpo celular por itens chamados pesos [ wi ], emulando as sinapses neurais. Seu funcionamento dá-se da seguinte forma: as excitações captadas nas entradas são processadas pela função de soma $\left[\sum\right.$ ], e o fronteira excitatória é constituída por uma função de ativação, também conhecida por transferência $[\theta]$. A figura 2 abaixo elucida essa especificação:

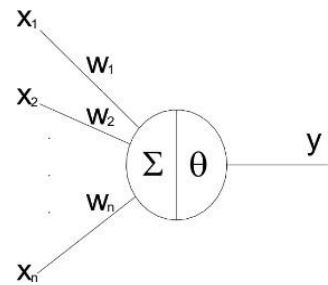

Figura 2. Modelo do neurônio de McCuloch e Pitts (Fonte: Adaptado de BRAGA et al., 2000)

Ainda conforme Braga et al. (2000), a respectiva ativação se dá pelo emprego de uma função de ativação que, dependendo do valor da soma ponderada das suas entradas, pode ativar ou não a saída; obedecendo a seguinte equação: $\sum_{i=1}^{n} x_{i} w_{i} \geq \theta$. A Figura 3 exemplifica o processo de sinapse neural artificial.

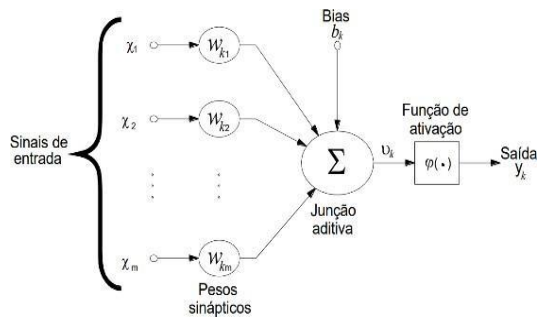

Figura 3. Modelo base de um neurônio artificial (Fonte: Adaptado de Haykin, 2001)

\section{MATERIAIS E MÉTODOS}

\subsection{Considerações Iniciais}

Utilizou-se, como fonte de dados, a base de dados pública do Sistema Eletrônico de Informações (SEI), desenvolvida pelo Tribunal Regional Federal da $4^{\mathrm{a}}$ Região (TRF4), sendo este um instrumento de gestão de documentos e processos eletrônicos, e tem como desígnio promover a eficiência administrativa. O SEI integra o Processo Eletrônico Nacional (PEN), um empreendimento conjunto de órgãos e entidades de distintas esferas da administração pública, com a finalidade de edificar uma infraestrutura pública de processos e documentos administrativos eletrônicos. Fazendo-se uso dessa base de dados, o ensaio ocorreu nas seguintes fases: 
a) Definição de um procedimento de aprendizagem de máquina - algoritmo, correspondente a realidade de cartéis, onde o conjugado - treino/teste; se deu com o conjunto de dados públicos de licitação;

b) Validação do algoritmo em escala geral - com a base de dados do Cade, sendo aplicado em sua totalidade.

\subsection{Construção do Algoritmo}

Houve propositura, para a solução necessária, de subdividir o sistema em três camadas distintas:

a) Entrada: utiliza os dados da experimentação, permitindo rotular a percepção do cenário de cartelização;

b) Intermediação ou Escondido: manuseia os dados da etapa anterior - Entrada, para aplicar sobre eles as equações de inferência matemática; possibilitando também a rotulagem de cenários percebidos pelo usuário. É aqui que ocorre o direcionamento para a topologia da RNA a ser empregue - número de camadas, unidades em cada camada, parâmetros do algoritmo de treino/teste e função de ativação. Neste momento há ampla colisão no desempenho da RNA de aprendizado resultante;

c) Saída: Rede Neural que maneja os dados da Intermediação e efetua o conjugado - treino/teste; possibilitando aprendizado de máquina, bem como sua validação. Nesta etapa ocorre o emprego do paradigma neural apropriado ao cenário de cartelização.

Para o conjugado - treino/teste; houve seleção, de forma estocástica, dos dados de licitações de caráter público, advindos do Tribunal de Contas do Distrito Federal e anexados ao bando de dados público do SEI. Para efeito de exemplificação, utilizou-se uma arquitetura de RNA com 03 camadas; pois a camada de entrada é normalmente excluída quando se conta o número de camadas em uma RNA.

Nesta pesquisa, optou-se pelo algoritmo de retropropagação (Backpropagation) para treinar a RNA com os critérios de parada: máximo de 10.000 (dez mil) iterações ou soma quadrática de erro menor que 0.1 (10-1), sendo este o padrão de trabalho adotado no CADE. A vantagem fundamental em se usar o Backpropagation é que o mesmo trabalha com multicamadas, se prestando a resolver problemas não-linearmente separáveis. Os dados persistidos arranjaram-se como treino para o aprendizado do modelo não paramétrico em questão - RNA.

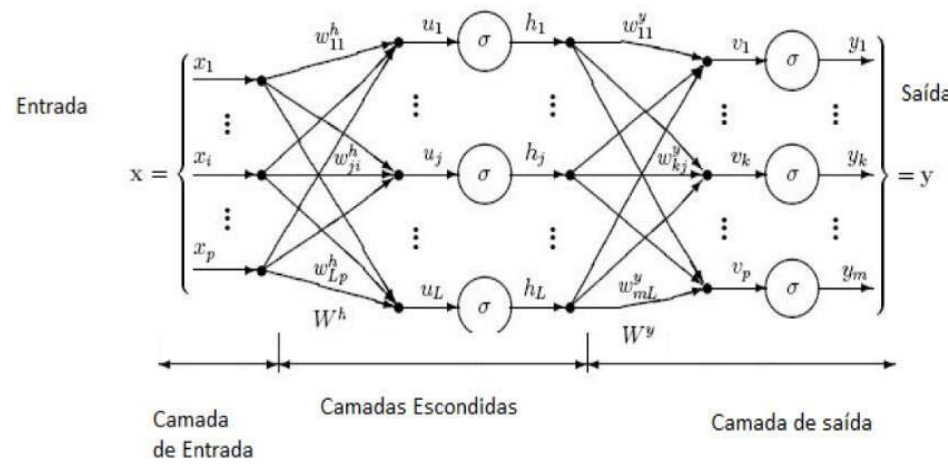

Figura 4. RNA do experimento: cada nó representa um neurônio e as setas suas respectivas sinapses

(Fonte: https://www.dtreg.com/solution/view/21, acessado em: 10/05/2019, às 16h:40min)

\subsection{Experimentação}

Neste experimento em questão, a detecção do conjunto de padrões do conjugado [treino/teste] da topologia da RNA deu-se com diversas variáveis de entrada que, por motivos de sigilo de inquérito do MJSP/Cade, não serão explicitadas aqui. De acordo com o autor clássico (BAWAZEER, 1996), escolhe-se, em média, $70 \%$ do volume de dados para treino e 30\% para teste. Do volume de dados coletados a partir do SEI e TCDF, escolheram-se, aleatoriamente, para [treino/teste] uma massa com percentual de $70 \%$ para treino e $30 \%$ para teste. Para a implementação da RNA foi utilizada a distribuição de código aberto (open-source) Anaconda, versão 2019.03, com que facilmente cria-se redes neurais, além de todo o tratamento ao dado - carga, limpeza, transformação e exibição; como também, com o Anaconda, é possível avaliar desempenho de qualquer RNA. 


\subsection{Validação}

A validação da RNA foi realizada nas acomodações do Laboratório de Computação Pervasiva - Lab, no próprio CADE e, após estruturada, foi treinada/testada de forma a alcançar eficiência máxima; onde os parâmetros de entrada são informados ao modelo. Tal implementação foi tipo feed-forward, onde os pesos sinápticos da primeira camada derivam das entradas, e os pesos das camadas seguintes decorrem das camadas que antecedem. A função de ativação, necessária a toda RNA, foi o tipo sigmóide logarítmica - com propagação positiva (Feed-forward) e que carecem em sua saída números exclusivamente positivos.

No tocante ao treinamento, utilizou-se o algoritmo - gradiente de retropropagação, onde os pesos são modificados na direção que reduz a respectiva soma quadrática dos erros ou, especificando com mais detalhes, sua função de desempenho. Estruturou-se a RNA em três camadas; sendo que a contagem de neurônios de cada camada satisfaz as necessidades de busca por cartelização e/ou lavagem de dinheiro e, por questões de sigilo de investigação do Ministério da Justiça (MJ), não será detalhado neste artigo.

\subsection{Análise dos Resultados}

Conforme a Figura 5, verifica-se os resultados alcançados na fase de treino da RNA. Averígua-se ainda uma excelente convergência entre resultados conhecidos - valor do laboratório (casos conhecidos e confirmados) e os alcançados pela RNA - valor da RNA (casos investigados pela rede neural).

$\mathrm{O}$ significado dos números nos eixos $\mathrm{X}$ e Y são, para todos os gráficos nessa pesquisa, a saber:

a) $\mathrm{X}$ - valor de correlação, quando positivo (maior que zero) indica um possível ilícito; quando zero, indica possível normalidade; caso contrário (negativo) indica um outlier - apresenta um grande afastamento dos demais da série, ou é inconsistente;

b) Y - quantidade de iterações necessárias pra RNA identificar o valor de correlação (X).

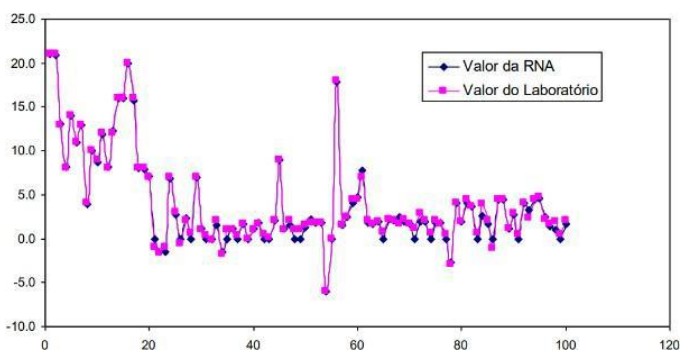

Figura 5. Valores do treino da RNA na detecção de cartéis (Fonte: Os autores, 2019)

A Figura 6 exibe as decorrências da validação na fase teste, conforme segue. Percebe-se que apesar de aderente aos dados e resultados da fase treino, a RNA ainda precisa ser otimizada para performance ou desempenho máximo, pois ainda há discrepâncias em algumas situações que sugerem ilícitos a ordem econômica, mas que de fato não é um caso concreto ou não existem.

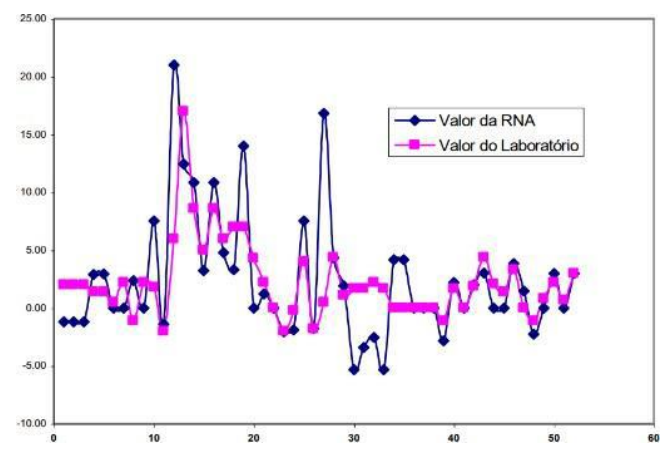

Figura 6. Validação da RNA (Fonte: Os autores, 2019) 
Segue, conforme figura 7, resultados advindos de comparativo da RNA com software comercial - Qlik Analytics Platform, da empresa QlikTech, fundada em 1993 em Lund, Suécia e atualmente sediada em King of Prussia, Pensilvânia, Estados Unidos.

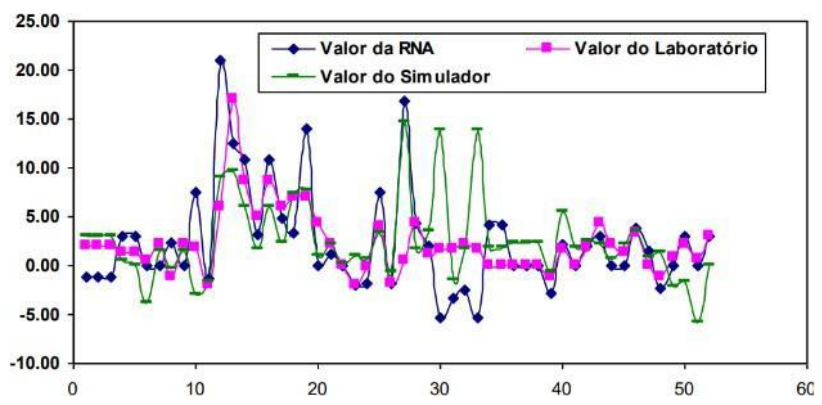

Figura 7. Confronto da RNA e o Simulador (Qlik Analytics Platform) - Fonte: Os autores, 2019

Embora nossos resultados de aprendizado não garantam que possamos encontrar uma solução para todos os problemas solucionáveis no domínio do MJSP, nossas análises e resultados mostraram que, na prática, o esquema de retropropagação leva a soluções em praticamente todos os casos. Em suma, acreditamos que respondemos as necessidades do Cade e encontraramos um resultado de aprendizado para demonstrar que seu emprego é válido.

Em muitas ocasiões, ficamos surpresos ao conhecer novos métodos de uso e funções das RNA(s), observando o comportamento de nosso algoritmo de aprendizado. Isso também levantou a questão da generalização. Na maioria dos casos que ocorrem no Cade, é interessante perguntar o que aconteceria se apresentássemos apenas um subconjunto dos exemplares no tempo de treinamento e depois observássemos o sistema generalizando para os exemplares restantes. Em pequenos problemas, como os apresentados aqui neste experimento em estudo, o sistema às vezes encontra soluções para os problemas que não são propriamente generalizados. No entanto, resultados preliminares em problemas maiores são muito encorajadores nesse sentido.

\section{CONCLUSÕES}

Foi acessada a Base de dados científica Scopus e pesquisado o tema central "neural networks", equivalente a "redes neurais" na língua portuguesa, com resultado de 417.559 (quatrocentos e dezessete mil e quinhentos e cinquenta e nove) pesquisas relacionadas em todo o território mundial do ano 1956 a 2019. Logo após foi introduzido o tema recorte "cartels" - cartéis, para detectar a quantidade de pesquisas que relacionava redes neurais/cartéis. Foram gerados 24 documentos. A partir dessa análise bibliométrica constata-se que as pesquisas referentes a conexão dos dois temas ainda são bastante incipientes.

Esta pesquisa ainda está em andamento e não pode ser relatada aqui como definitiva; pois estamos na vanguarda em tecnologias derivadas de IA. Este é, atualmente, um interesse muito ativo em nossos trabalhos internos.

Os experimentos confirmaram a eficácia da modelagem com redes complexas em uma das aplicações mais tradicionais em IA: deteç̧ão de padrões. As RNA(s) foram usadas com sucesso para reconhecimento de padrões com qualidade por taxas de acerto definidas por métricas hierárquicas em redes complexas, refletindo que bons resultados tendem a ser encontrados, até mesmo em contextos mais amplos.

Finalmente, devemos dizer que, não estando o trabalho finalizado, pois apenas começamos nosso estudo de RNA(s), ainda não aplicamos nosso procedimento de aprendizagem a problemas muito complexos - redes de carteis interestaduais e/ou lavagem de dinheiro em toda a esfera nacional e/ou internacional. No entanto, os resultados até o momento são encorajadores e continuamos nosso trabalho. 


\section{AGRADECIMENTO}

Os autores agradecem o apoio das Agências brasileiras de pesquisa, desenvolvimento e inovação CNPq (Projeto INCT em Segurança Cibernética 465741/2014-2), CAPES (Projetos FORTE 23038.007604/2014-69 e PROBRAL 88887.144009/2017-00) e Fundação de Apoio à Pesquisa do Distrito Federal FAPDF (Projetos UIoT 0193.001366/2016 e SSDDC 0193.001365/2016), bem como ao Laboratório LATITUDE/UnB (Projeto SDN 23106.099441/2016-43) e ao Conselho Administrativo de Defesa Econômica (Cade/MJSP).

\section{REFERÊNCIAS}

Akhgar, B., Bayerl, P. S. e Sampson, F. (2016) Open Source Intelligence Investigation: From Strategy to Implementation, Springer International Publishing.

Antiqueira, L; Nunes, M. G. V.; Oliveira JR., O. N.; Costa, L.F. (2007) Strong correlations between text quality and complex networks features. Physica A, 373:811-820.

Bawazeer, A.S. (1987) The fishery management of the stock of chim, the giant sea catfish Arius thalassinus in Kuwait waters. Kuwait Bull. Mar. Sci,. 9:87-100.

Biembengut, M. S.; Hein, N. (2003) Modelagem matemática no ensino. São Paulo: Contexto.

Braga, A. de.; Ludermir, T. B.; Carvalho, A. C. P. de L. F. (2000) Redes Neurais Artificiais - Teoria e Aplicações, Rio de Janeiro: LTC - Livros Técnicos e Científicos Editora S.A.

Brasil (2008) Departamento de Proteção e Defesa Econômica da Secretaria de Direito Econômico do Ministério da Justiça. Combate a cartéis em licitações - guia prático para pregoeiros e membros de comissões de licitação. Brasília. Disponível em <http://www.comprasnet.gov.br/banner/seguro/cartilha_licitacao.pdf>. Acesso em 19 de maio de 2019.

Brasil (2011) Lei 12.529, de 30 de novembro de 2011. Disponível em <http://www.planalto.gov.br/ccivil_03/_Ato2011-2014/2011/Lei/L12529.htm>. Acesso em 19 de maio de 2019.

Carvalho, F. L. E. (2013) A Política Antitruste no Brasil e o Combate a Cartéis à Luz do Novo CADE. Revista Thesis Juris - São Paulo, V.2, N.2, pp. 473-500.

Haykin, S. (2001) Redes Neurais: Princípios e Prática. 2. ed. Porto Alegre, Bookman.

Market Business News (2017) "What is the OECD? Definition and Meaning". Disponível em <https://marketbusinessnews.com/financial-glossary/oecd-definition-meaning/>. Acesso em 19 de maio de 2019.

Strogatz, S. H. (2001) Exploring complex networks. Nature, 410:268-276. Disponível em: <http://dx.doi.org/10.1038/35065725>. Acesso em 06 de maio de 2019.

Tafner, M.A.; Xeres M.; Rodrigues-Filho I.W. (1995) Redes Neurais Artificiais: Introdução e Princípios de Neuro-computação, 1a ed.. Blumenau, EKO, Ed. da Furb. 